\title{
Case-control study of Epstein-Barr virus and Helicobacter pylori serology in Latin American patients with gastric disease
}

\begin{abstract}
M G Cárdenas-Mondragón ${ }^{1}$, J Torres ${ }^{1}$, L Flores-Luna ${ }^{2}$, M Camorlinga-Ponce ${ }^{1}$, R Carreón-Talavera ${ }^{1}$, A Gomez-Delgado ${ }^{1}$, E Kasamatsu ${ }^{3}$ and E M Fuentes-Pananá*,4

${ }^{1}$ Unidad de Investigación Médica en Enfermedades Infecciosas y Parasitarias (UIMEIP), Hospital de Pediatría, CMN Siglo-XXI, Instituto Mexicano del Seguro Social (IMSS), Avenida Cuauhtémoc 330, Colonia Doctores, Delegación Cuauhtémoc, Ciudad de México, DF, CP 06720, México; ${ }^{2}$ Centro de Investigación en Salud Poblacional, Instituto Nacional de Salud Pública, Avenida Universidad 655, Colonia Santa María Ahuacatitlán, Cuernavaca, Morelos, CP 62100, México; ${ }^{3}$ Instituto de Investigaciones en Ciencias de la Salud, Universidad Nacional de Asunción, Tte. Fariña 1076 e/Brasil y EE.UU, PB Dpto. B., Asunción, Paraguay and ${ }^{4}$ Unidad de Investigación en Virología y Cáncer, Hospital Infantil de México, Federico Gómez, Dr Márquez 162, Colonia Doctores, Delegación Cuauhtémoc. Ciudad de México, DF, CP 06720, México
\end{abstract}

Background: Chronic tissue damage induced by Helicobacter pylori (HP)-driven inflammation is considered the main risk of gastric carcinoma (GC). Epstein-Barr virus (EBV) infection has also been associated with GC. In this study, we aim to address the role of EBV in inflammatory GC precursor lesions and its added risk to HP infection.

Methods: Antibodies against EBV, HP and the bacterial virulence factor CagA were measured in sera from 525 Mexican and Paraguayan patients with gastric disease. Gastric samples were characterised according to the updated Sydney classification and associations were estimated between antibody responses and severity of both tissue damage and inflammation.

Results: We found significant associations (odd ratios and trends) between EBV and HP copositivity and premalignant lesions and intestinal-type GC. The EBV and HP coinfection was also significantly associated with increased infiltration of immune cells. No association was found between EBV and the less inflammation-driven diffuse-type GC.

Conclusions: Our study suggests that EBV co-participates with HP to induce severe inflammation, increasing the risk of progression to intestinal-type GC.

Gastric carcinoma (GC) is the fifth most common type of cancer and the third cause of death by cancer worldwide, affecting particularly Asian and Latin American countries (Ferlay et al, 2013). According to the Lauren classification, there are two main histological types of gastric adenocarcinoma, intestinal and diffuse, that presumably evolve through different mechanisms. Intestinaltype GC progresses through inflammatory lesions characterised by increased tissue damage, starting with a nonatrophic gastritis (NAG) that becomes an atrophic gastritis (AG), intestinal metaplasia (IM), dysplasia and eventually GC (the so-called Correa sequence) (Correa et al, 1975). Although diffuse GC also initiates through NAG, it does not progress through intermediate atrophic/ inflammatory lesions, and it has been suggested that it may be importantly driven by causes other than inflammation, including germline mutations. In agreement, familial GC cases resulting from inherited E-cadherin mutations usually develop diffuse type of GC (Guilford et al, 1998); still, the carcinogenic process remains unknown for most cases.

Gastric carcinoma is a cancer of a recognised infectious aetiology, with Helicobacter pylori $(H P)$ considered the main risk 
factor and, more recently, also linked to infection by Epstein-Barr virus (EBV) (Murphy et al, 2009; Camargo et al, 2011). Both pathogens are usually acquired early in life, with $\sim 50 \%$ of the adult world population infected by $H P$ and $90 \%$ by EBV (Thorley-Lawson and Gross, 2004; Fuccio et al, 2010). Carcinogenic pathogens are classified as direct or indirect acting according to their transforming mechanisms (Morales-Sanchez and FuentesPanana, 2014). The direct-acting agents are usually found in monoclonal form in tumour cells and keep the transformed phenotype through aberrant expression of pathogen and/or cellular oncogenes and tumour suppressor genes. Indirect agents promote the transformation process without housing in the tumour cell, either triggering local chronic inflammation and oxidative stress that persistently damage the infected tissue or triggering immunosuppression affecting tumour immunosurveillance mechanisms. Although $H P$ is considered the prototype cancerinducing agent through chronic inflammation/tissue damage mechanisms, a direct-transforming bacterial oncogene, cagA (cytotoxin-associated gene $A$ ), has been recently documented (Ohnishi et al, 2008; Miura et al, 2009). On the other hand, EBV is considered a direct transforming pathogen through expression of its own death/proliferation regulatory genes (Thornburg et al, 2006; Frappier, 2012; Shair et al, 2012; Saha and Robertson, 2013).

The EBV infection has been associated with several types of B-cell lymphomas and upper digestive tract carcinomas. The EBV infection usually persists in B cells, with most infected individuals carrying the virus asymptomatically in a latent stage in these cells. It is not clear how EBV infects the gastric mucosa and whether infection induces an inflammatory reaction, as observed with $H P$. We have recently presented evidence of an association between EBV reactivation antibodies and severe inflammatory responses in the gastric mucosa of pediatric patients (Cardenas-Mondragon et al, 2013). In the present study, a role of EBV in premalignant and malignant lesions was addressed in adult patients from two Latin American countries with similar GC risk and HP prevalence (Flores-Luna et al, 2012). For this, antibodies against the viral capsid antigen (VCA), an EBV reactivation antigen, HP and the CagA virulence factor were analysed for association with the type of gastric lesion and the degree of inflammation. We found evidence suggesting a critical EBV activity promoting inflammation of the gastric epithelium that, together with $H P$, increases the risk of developing premalignant lesions and intestinal-type GC.

\section{MATERIALS AND METHODS}

Ethics statement. The Scientific and Ethics Committees from each of the participating hospitals approved this study: Hospital de Especialidades and Hospital de Oncologia of the Centro Médico Nacional Siglo XXI (Instituto Mexicano del Seguro Social; IMSS), Hospital General de México 'Eduardo Liceaga' and Hospital de Cancerología of the Secretaría de Salud (SS) in Mexico City, and the Universidad Nacional de Asunción in Paraguay. All patients were informed about the nature of the study and those willing to participate signed a written informed consent before specimen collection.

Study design. This is a case-control study of patients with gastric disease in which antibodies against an EBV reactivation antigen, $H P$ and the CagA virulence factor were analysed for association with the type of gastric lesion and the degree of inflammation. For all analyses performed premalignant (AG, IM and dysplasia) and malignant lesions (cases) were compared with NAG (controls), the earliest inflammatory lesion in the progression to intestinal and diffuse GC.

Study population. The study included 525 adult patients $(\geq 30$ years old) with any spectrum of gastric lesion from Mexico and
Paraguay, two Latin American countries with reported similar rates of HP infection, prevalence of CagA-positive strains and GC incidence (Flores-Luna et al, 2012). Patients were recruited between October 1999 and July 2002 after attending the Gastroenterology or Oncology Units because of gastric symptoms or a probable GC. Patients were recruited from the following hospitals: Hospital de Especialidades and Hospital de Oncología of the Centro Médico Nacional Siglo XXI (Instituto Mexicano del Seguro Social (IMSS)), Hospital General de México 'Eduardo Liceaga' and Hospital de Cancerología of the Secretaría de Salud (SS) in Mexico City, and the Universidad Nacional de Asunción in Paraguay. A total of 813 patients were recruited, of whom 236 were eliminated from Mexico and 52 from Paraguay because of lacking complete information about either the histopathological or serological analysis. Thus, 309 (Mexico) and 216 (Paraguay) patients were included in the study.

Healthy blood donors. Sera from 129 healthy blood donors (median age $=41.6 \pm 7.7 ; 0.98$ male to female ratio) were collected between September 2010 and April 2012 from the blood bank of the Centro Médico Nacional Siglo XXI (IMSS in Mexico City). Clinical information was registered in questionnaires at the time of inclusion with no reports of gastric symptomatology. The median of antibody titres for this group was: 72.7 (anti-EBV IgG), 1.2 (anti-HP IgG) and 1.0 (anti-CagA IgG).

Data collected. Sociodemographic data and clinical information were registered in questionnaires at the time of inclusion. The information collected included age, gender, clinical symptoms and clinical diagnosis based on endoscopy, histology and clinical presentation. Patients with antibiotic, bismuth compounds, proton pump inhibitors and/or nonsteroidal anti-inflammatory drugs or antiacid treatments 3 weeks before sample collection as well as those who had received cancer treatment were excluded from the study.

Histopathological examination. Three biopsies from the antrum and three from the body of the stomach were used for the histopathological diagnosis. All biopsies were fixed in formalin, embedded in paraffin and a section stained with haematoxylin and eosin (HE). The HE-stained sections were used to measure and classify the inflammatory reaction according to the updated Sydney system (Dixon et al, 1996). The pathologist involved in this study received direct training from a group of experts led by Dr Pelayo Correa. This group of experts validated all the samples collected after standardisation of the criteria using consensus protocol reading (Kasamatsu et al, 2010). Samples were classified according to the level of tissue damage and type of lesion as NAG, AG, IM, dysplasia, intestinal- and diffuse-type GC. Samples were also classified according to the level of immune cell infiltration of mononuclear (MN) cells (inflammation) and polymorphonuclear (PMN) cells (activity of the lesion) (Dixon et al, 1996). After reading all samples, the final diagnosis for both types of lesion and level of infiltration was that of the most severe reading observed in the six biopsies analysed for each patient.

Collection of blood and analysis of antibodies. A sample of venous blood $(4 \mathrm{ml})$ was drawn from all patients. Stored serum samples were used to analyse IgG, IgM and IgA antibodies against EBV VCA, as well as IgG antibodies against $H P$ whole-cell extracts and CagA. Anti-EBV VCA antibodies were determined using ELISA commercial kits (HUMAN, Wiesbaden, Germany) for IgG anti-VCA (catalogue 51204) and for IgM anti-VCA (catalogue 51104), as well as IgA anti-VCA (catalogue 1414; Diagnostic Automation, Inc., Calabasas, CA, USA) following the manufacturer's instructions and as previously described (CardenasMondragon et al, 2013). Anti-EBV IgG-positive samples were defined after comparison with a cutoff value (COV). This COV was calculated with the following formula: $\mathrm{COV}=$ (mean 
absorbance of negative controls $+((0.1)$ (mean absorbance of positive controls)). Sample values are expressed in $\mathrm{HU} \mathrm{ml}^{-1}=$ mean absorbance of sample/[(mean absorbance values of positive control) (100)]. The sample is considered positive when the mean absorbance value (after two or four readings) was above the COV calculated $+15 \%$. The COV is independently calculated for each ELISA plate and a mean of 20.1 was obtained between plates. The IgG antibodies against $H P$ and CagA were determined using ELISA tests previously used and validated in a Mexican population (Camorlinga-Ponce et al, 1998; Cardenas-Mondragon et al, 2013). Patients were considered positive for HP antibodies when ELISA units were $\geq 1.0$, and for CagA when ELISA units were $\geq 1.5$, according to the validated cutoffs (Camorlinga-Ponce et al, 1998).

Statistical analysis. The data set was analysed using different statistical tools assessing whether the data followed a normal or nonnormal distribution. We then compared Mexico and Paraguay using the media and the s.d. for all descriptive analyses: differences in age were estimated by the Student's $t$-test, and for categorical variables (sex, type of gastric lesions; EBV, HP and CagA serology) frequencies were obtained, and differences were estimated by the proportion test. Because no significant differences were found, both populations were added and analysed together. The proportion test was also used to analyse differences in the frequency of seropositive patients between gastric lesions: premalignant and malignant lesions against NAG, or intestinal-type against diffuse-type GC. For all comparisons between more than two categories, the Mantel-Haenszel $\chi^{2}$ with linear tendency was used. In all these analyses the least advanced lesion was used as control: NAG for premalignant and malignant lesion, and none/ mild PMN and MN infiltration as control for severe immune cell infiltration. To assess the risk provided by EBV, $H P$ or CagA to develop premalignant and malignant lesions or severe immune cell infiltration, the odd rates (ORs) were estimated. The group of EBV and HP double-positive patients was compared with the group infected with only $H P$ or EBV. A similar analysis was performed with $\mathrm{HPCagA}+/ \mathrm{EBV}+$ against $\mathrm{HPCagA}-/ \mathrm{EBV}+$ and HPCagA + /EBV - . Premalignant and malignant lesions were compared with NAG and severe immune infiltration against none or mild. Because sex and age are confounders, ORs were adjusted by them using logistic regression with $95 \%$ confidence intervals (CIs). Sex- and age-adjusted ORs were also used to estimate whether increased anti-EBV antibody titres were associated with premalignant and malignant lesions. For this analysis the EBV antibody titre was categorised by tertiles based in their distribution in NAG followed by a comparison of the highest to the lowest tertiles. Tests for trend were conducted by modelling tertile median serological values to asses increased risk when progressing from NAG to premalignant to malignant lesions; from non/mild to moderate to severe immune cell infiltration; and from low to moderate to high anti-EBV antibody titres. Data were analysed using the statistical Stata 12.0 software program (Stata Corporation, College Station, TX, USA) and Epi Info 7 TM (Centers for Disease Control and Prevention (CDC, Atlanta, GA, USA)).

\section{RESULTS}

Study population. The study included 525 adult patients who sought medical attention for gastric diseases in Mexico and Paraguay. The demographic characteristic of the patients and the seroprevalence of anti-EBV, anti-HP and anti-CagA antibodies are summarised in Table 1. A total of 225 (42.9\%) samples were classified as NAG with typical epithelial cell morphology and no glandular atrophy, and 300 samples presented atrophy and were grouped according to the presence of malignant changes: $186(35.4 \%)$ premalignant lesions $(\mathrm{AG}=27, \mathrm{IM}=152$ and
Table 1. General description of the study population

\begin{tabular}{|c|c|c|c|}
\hline Variable & Mexico & Paraguay & Total \\
\hline Number studied (\%) & 309 & 216 & 525 \\
\hline Age (mean \pm s.d.) $)^{a}$ & $54.7 \pm 13.9$ & $54 \pm 15.1$ & $54.4 \pm 14.4$ \\
\hline Sex, male/female ratio & $126 / 183=0.69$ & $118 / 98=1.2$ & $244 / 281=0.87$ \\
\hline \multicolumn{4}{|l|}{ Gastric lesion, n (\%) } \\
\hline Nonatrophic gastritis $^{\mathbf{b}}$ & $124(40.1)$ & $101(46.8)$ & $225(42.9)$ \\
\hline Premalignant lesions ${ }^{b}$ & $123(39.8)$ & $63(29.2)$ & $186(35.4)$ \\
\hline Gastric cancer $(\mathrm{GC})^{\mathbf{b}}$ & $62(20.1)$ & $52(24.1)$ & $114(21.7)$ \\
\hline Intestinal type $\left(\%^{c}\right)^{b}$ & $30(48.4)$ & $20(38.5)$ & $50(43.9)$ \\
\hline Diffuse type $\left(\%^{c}\right)^{b}$ & $32(51.6)$ & 32 (61.5) & $64(56.1)$ \\
\hline EBV positive, $n(\%)^{b}$ & $291(94.2)$ & 206 (95.4) & 497 (94.7) \\
\hline HP positive, $n(\%)^{\mathrm{b}}$ & $270(87.4)$ & 189 (87.5) & $459(87.4)$ \\
\hline CagA positive, $n(\%)^{b}$ & 219 (70.9) & $163(75.5)$ & $382(72.8)$ \\
\hline \multicolumn{4}{|c|}{$\begin{array}{l}\text { Abbreviations: CagA = cytotoxin-associated gene A; EBV=Epstein-Barr virus; } H P= \\
\text { Helicobacter pylori. } \\
\text { a Student's t-test. } \\
\text { b Proportion test. } \\
{ }^{c} \text { Referred to GC (100\%). }\end{array}$} \\
\hline
\end{tabular}

dysplasia $=7)$ and $114(21.7 \%)$ GCs. Of these 114, 50 GCs were intestinal type and 64 were diffuse type.

Reactivation of EBV has been documented to occur in the mucosa of the upper GI tract and antibodies against lytic-cycle antigens mirror the level of viral reactivation and correlate with the risk to develop nasopharyngeal carcinoma (NPC; Ji et al, 2007). To address whether EBV reactivation also correlates with GC progression, IgG and IgA antibodies against VCA were measured in all patients. The IgM antibodies were also initially measured, but because only a few samples were positive, and IgM-positive patients preferentially presented NAG, we did not continue that analysis. In all, 497 (94.7\%) patients were positive for EBV antibodies, with a similar prevalence in both countries (Table 1). Most patients were positive for IgG antibodies, with only 120 (22.9\%) also positive for IgA. The median of the anti-VCA IgG titre was $80.4 \mathrm{HU} \mathrm{ml}^{-1}$ (range 18-181.1 units), whereas IgA tests were not quantitative. Seroprevalence to $H P$ and CagA was $87.4 \%$ and $72.8 \%$, respectively. The $H P$ infection frequencies in both countries were also highly similar. The coefficient of variation $(\mathrm{CV})$ of all serological measurements was very similar for both countries, with CV average values of 45.1 for EBV, 85 for $H P$ and 77.8 for CagA.

EBV serology positively associates with premalignant lesions and intestinal type GC. The frequency of EBV positivity (IgG + with either $\operatorname{IgA}+$ or $\operatorname{Ig} \mathrm{A}-$ ) was estimated for each disease group and premalignant lesions (AG, IM and dysplasia) and malignant lesions were compared with NAG, the earliest stage in GC progression (Table 2). A proportion test showed significant values for premalignant lesions $(P=0.009)$ and intestinal-type GC $(P=0.039)$. A significant $\mathrm{OR}$ was also found with premalignant lesion $(\mathrm{OR}=3.5)$, whereas intestinal GC showed an infinite $(\infty)$ value because all cases were EBV positive (Table 2). Moreover, the frequency of positives from NAG to premalignant lesion and to intestinal-type GC showed a significant trend $(P=0.003)$. On the other hand, no association was found between EBV seropositivity and the diffuse type of GC. The EBV IgA-positive patients did not show any significant association (data not shown). Similar results were obtained comparing with sera from a group of 129 healthy blood donors (data not shown), although the analysis with this group was not pursued because of lack of tissue to evaluate gastric disease. Regarding HP, we observed HP or CagA associated with premalignant lesions, the frequency of positives to both of these risk factors decreased in intestinal type of GC but it was maintained in the diffuse type. This trend in HP serology 
Table 2. EBV and H. pylori association with advanced stages of gastric disease

\begin{tabular}{|c|c|c|c|c|c|}
\hline \multirow[b]{3}{*}{ lgG titres } & \multicolumn{5}{|c|}{ Gastric lesion } \\
\hline & \multirow[b]{2}{*}{$\mathrm{NAG}^{a}$} & \multirow[b]{2}{*}{ Premalignant lesions } & \multicolumn{3}{|c|}{ Gastric cancer } \\
\hline & & & Intestinal & Diffuse & Total GC \\
\hline Total, $\mathbf{M}+\mathbf{P}$ & $n=225$ & $n=186$ & $n=50$ & $n=64$ & $n=114$ \\
\hline \multicolumn{6}{|l|}{ EBV } \\
\hline $\begin{array}{l}\text { Positive, } n(\%) \\
P^{b} \\
\text { OR }^{c}(95 \% \text { Cl) } \\
P \text { for trend }\end{array}$ & 207 (92) & $\begin{array}{c}182(97.9) \\
0.009 \\
3.5(1.1-10.8)\end{array}$ & $\begin{array}{c}50(100) \\
0.039 \\
\infty \\
0.003\end{array}$ & $\begin{array}{c}58(90.6) \\
0.489 \\
0.7(0.2-2.1) \\
0.577\end{array}$ & $\begin{array}{c}108(94.7) \\
0.375 \\
1.2(0.4-3.4) \\
0.163\end{array}$ \\
\hline \multicolumn{6}{|l|}{ HP } \\
\hline $\begin{array}{l}\text { Positive, } n(\%) \\
P^{b} \\
\text { OR }^{c}(95 \% \text { Cl) } \\
P \text { for trend }\end{array}$ & $193(85.8)$ & $\begin{array}{c}166(89.3) \\
0.319 \\
1.7(0.9-3.2)\end{array}$ & $\begin{array}{c}40(80) \\
0.352 \\
0.9(0.3-2.5) \\
0.756\end{array}$ & $\begin{array}{c}60(93.8) \\
0.099 \\
3.2(1.01-10.9) \\
0.068\end{array}$ & $\begin{array}{c}100(87.7) \\
0.652 \\
1.6(0.7-3.5) \\
0.493\end{array}$ \\
\hline \multicolumn{6}{|l|}{ CagA } \\
\hline $\begin{array}{l}\text { Positive, } n(\%) \\
P^{b} \\
\text { OR }^{\mathrm{c}}(95 \% \mathrm{Cl}) \\
P \text { for trend } \\
\end{array}$ & $157(69.8)$ & $\begin{array}{l}147(79) \\
0.067 \\
1.8(1.1-3.0)\end{array}$ & $\begin{array}{c}28(56) \\
0.150 \\
0.9(0.4-2.1) \\
0.647\end{array}$ & $\begin{array}{c}50(78.1) \\
0.256 \\
1.8(0.9-3.9) \\
0.052\end{array}$ & $\begin{array}{c}78(68.4) \\
0.827 \\
1.2(0.7-2.0) \\
0.824\end{array}$ \\
\hline \multicolumn{6}{|c|}{$\begin{array}{l}\text { Abbreviations: CagA = cytotoxin } \\
\text { patients, Mexico + Paraguay; NA } \\
\text { a Used as control group. } \\
\text { b Proportion test for positive sam } \\
{ }^{c} \text { OR adjusted for age and sex. } \\
{ }^{d} \text { The } \chi^{2} \text { for trend of positives (\% }\end{array}$} \\
\hline
\end{tabular}

Table 3. The HP/EBV coinfection and risk to develop advanced gastric disease

\begin{tabular}{|c|c|c|c|c|c|c|c|c|c|}
\hline & \multicolumn{9}{|c|}{ Gastric lesion } \\
\hline & \multirow{3}{*}{$\begin{array}{c}\begin{array}{c}\text { Nonatrophic } \\
\text { gastritis }^{\mathrm{a}}\end{array} \\
\mathbf{N}\end{array}$} & & & \multicolumn{6}{|c|}{ Gastric cancer } \\
\hline & & \multicolumn{2}{|c|}{ Premalignant lesion } & \multicolumn{2}{|c|}{ Intestinal } & \multicolumn{2}{|r|}{ Diffuse } & \multicolumn{2}{|c|}{ Total GC } \\
\hline Groups & & $N$ & $\mathrm{OR}^{\mathrm{b}}(95 \% \mathrm{Cl})$ & $N$ & $\mathrm{OR}^{\mathrm{b}}(95 \% \mathrm{Cl})$ & $N$ & $\mathrm{OR}^{\mathrm{b}}(95 \% \mathrm{Cl})$ & $N$ & $\mathrm{OR}^{\mathrm{b}}(95 \% \mathrm{Cl})$ \\
\hline $\mathrm{HP}+/ \mathrm{EBV}+\mathrm{vs}$ & 175 & 164 & $8.4(1.8-38.9)$ & 40 & & 55 & $0.9(0.3-2.9)$ & 95 & $1.5(0.5-4.7)$ \\
\hline $\mathrm{HP}+/ \mathrm{EBV}-$ & 18 & 2 & $P=0.007$ & 0 & $\infty$ & 5 & $P=0.912$ & 5 & $P=0.502$ \\
\hline $\mathrm{HP}+/ \mathrm{EBV}+\mathrm{vs}$ & 175 & 164 & $2.0(1.01-3.9)$ & 40 & $1.0(0.4-2.8)$ & 55 & $4.5(1.2-17.4)$ & 95 & $2.0(0.8-4.6)$ \\
\hline $\mathrm{HP}-/ \mathrm{EBV}+$ & 32 & 18 & $P=0.047$ & 10 & $P=0.928$ & 3 & $P=0.027$ & 13 & $P=0.114$ \\
\hline HP CagA + /EBV + & 143 & 145 & $6.8(1.4-33)$ & 28 & & 45 & $0.7(0.2 .-2.3)$ & 73 & $1.1(0.3-3.6)$ \\
\hline HP CagA + /EBV - & 14 & 2 & $P=0.017$ & 0 & $\infty$ & 5 & $P=0.567$ & 5 & $P=0.885$ \\
\hline HP CagA + /EBV + & 143 & 145 & $1.7(0.9-3.2)$ & 28 & $0.9(0.3-2.6)$ & 45 & $1.1(0.4-2.6)$ & 73 & $1.0(0.5-2.2)$ \\
\hline HP CagA - /EBV + & 32 & 19 & $P=0.132$ & 12 & $P=0.899$ & 10 & $P=0.869$ & 22 & $P=0.966$ \\
\hline \multicolumn{10}{|c|}{$\begin{array}{l}\text { Abbreviations: } \text { CagA }=\text { cytotoxin-associated gene } \mathrm{A} ; \mathrm{Cl}=\text { confidence interval; } \mathrm{EBV}=\text { Epstein-Barr virus; } \mathrm{GC}=\text { gastric cancer; } H P=\text { Helicobacter pylori; } \mathrm{OR}=\text { odds ratio. Numbers in bold denote } \\
\text { statistical significance }(P>0.05) \text {. } \\
\text { a Used as control group. }\end{array}$} \\
\hline
\end{tabular}

during GC progression has been previously documented by us (Camorlinga-Ponce et al, 2008) and others (Kokkola et al, 2003).

Because infection by $H P$ is considered the main risk factor to develop GC, we grouped patients according to their infection status as follows: 434 patients were positive for both pathogens $(H P+1$ $\mathrm{EBV}+$ ), 63 were positive only for EBV, 25 were positive for $H P$ and 3 patients were negative for both $H P$ and EBV. To better understand the added risk of both pathogens to develop gastric lesions, we have taken the individuals infected by both pathogens and compared them with the ones infected only by HP (to estimate the added risk of EBV infection) or compared them with the ones infected only by EBV (to estimate the added risk of $H P$ infection) (Table 3). A significant $\mathrm{OR}=8.4$ was observed for premalignant lesions when $\mathrm{HP}+/ \mathrm{EBV}+$ was compared with $\mathrm{HP}+$ (which addresses the role of EBV, $P=0.007$ ), whereas in the case of intestinal-type GC, all patients were $\mathrm{EBV}+$, giving a $P$-value of $\infty$. No significant association was obtained with diffuse-type GC. When $H P+/ E B V+$ was compared with the EBV + group (which addresses the role of $H P$ ), the association between coinfection and premalignant lesions was also significant $(\mathrm{OR}=2.0 ; P=0.047)$. However, results with the types of GC differed; there was no association with the intestinal-type GC, but a significant association was observed with the diffuse-type $\mathrm{GC}(\mathrm{OR}=4.5 ; P=0.027)$. A similar analysis was performed comparing CagA $+/ E B V+$ with $\mathrm{CagA}+/ \mathrm{EBV}-$ patients, finding a significant value for premalignant lesions $(\mathrm{OR}=6.8 ; P=0.017$; Table 3$)$. 
The frequency of EBV- and HP-positive patients in the different disease groups is shown in Supplementary Figure 1, in which it can be observed that EBV positivity increases as the inflammatory lesion progresses (from NAG to premalignant lesion and intestinal $\mathrm{GC})$, whereas $H P$ decreases in intestinal GC patients. In contrast, the frequency of HP remains high in diffuse GC. Supplementary Table 1 shows a proportion test comparing the frequency of EBV or HP seropositivity between intestinal and diffuse GCs, showing that whereas EBV was significantly associated with intestinal GC $(P=0.026), H P$ and CagA were associated with diffuse GC $(P=0.036$ and $P=0.041$, respectively).

EBV serology positively associates with severe gastric inflammation. The association of EBV with intestinal-type GC and its precursor lesions suggests a possible role of EBV in collaboration with $H P$ to induce a more severe inflammatory process, considered as the main driver for this oncogenic pathway. To test this, the level of inflammation in each lesion was graded according to the updated Sydney system (Dixon et al, 1996) and ORs (for both infiltration of $\mathrm{MN}$ or PMN cells) were estimated between $\mathrm{EBV}+/ \mathrm{HP}+$ and single infected patients, either $\mathrm{HP}+$ or EBV + (Table 4). Because only a few samples presented severe PMNs, moderate and severe groups were combined. The analysis showed that patients with a mixed EBV and HP infection presented significant ORs for severe infiltration of both MN (OR of 5.9 in NAG; and OR of 18.3 in premalignant lesions) and PMN cells (OR of 11.5 in NAG, and OR of 10.2 in premalignant lesions) than patients with single infection. Also, an analysis of the trend of progression from less to more severe inflammation showed significant values for both $M N$ and $\mathrm{PMN}$ infiltration in $\mathrm{HP}+/ \mathrm{EBV}+$ patients with either NAG or premalignant lesions $(P<0.005$; Table 4$)$. Nonsignificant ORs of 3 and 7.5 for severe $\mathrm{MN}$ and PMN infiltration, respectively, were observed in intestinal-type GC. Similar positive associations were found when the double-positive EBV and CagA groups were compared with the group of CagA positive but EBV negative plus the EBV positive but CagA negative (Supplementary Table 2). Nonsignificant numbers were observed for diffuse-type GC (Supplementary Table 3).

Increased levels of antibodies against EBV were significantly associated with severity of disease. We then analysed whether increased antibody titres against EBV-VCA were also associated with premalignant lesion and intestinal-type gastric disease (Table 5). This analysis showed that increased antibody titres had a significantly increased association with premalignant lesions $(P$-value for trend $=0.023)$ and with intestinal GC $(P$-value for trend $=0.038)$. In contrast, no such significant trend was observed for diffuse GC.

\section{DISCUSSION}

In this study, we provide serological evidence suggesting that despite the decreased level of antibodies against $H P$ in intestinaltype GC, there is a significant association of EBV and $H P$ coinfection with this GC and its precursor lesions. We did not observe the same for the diffuse type of GC, although HP remained positively associated, suggesting that EBV reactivation does not importantly contribute to this pathway of gastric carcinogenesis. The intestinal and diffuse types of GC presumably evolve through different mechanisms. Intestinal-type GC progresses through inflammatory precursor lesions characterised by increased tissue damage (AG to IM to dysplasia). In agreement with the EBV association with this pathway, we also found a positive association between EBV and severe infiltration of PMN and MN immune cells, suggesting that EBV is an important trigger of inflammation. On the contrary, diffuse GC does not progress through intermediate atrophic/inflammatory lesions, and it has been
Table 4. Risk of increased inflammation in double-infected vs single-infected patients

\begin{tabular}{|c|c|c|c|c|}
\hline & $\begin{array}{c}\mathrm{HP}+ \\
\mathrm{EBV}+\end{array}$ & $\begin{array}{c}H P+E B V- \\
\text { and } \\
H P-E B V+\end{array}$ & & $\begin{array}{l}P \text { for } \\
\text { trend }^{\mathrm{a}}\end{array}$ \\
\hline & $N$ & $N$ & $\mathrm{OR}^{\mathrm{b}}(95 \% \mathrm{CI})$ & \\
\hline \multicolumn{5}{|l|}{ MN infiltration } \\
\hline $\begin{array}{l}\text { Nonatrophic gastritis } \\
\text { Mild }^{c} \\
\text { Moderate } \\
\text { Severe }\end{array}$ & $\begin{array}{r}32 \\
105 \\
38\end{array}$ & $\begin{array}{r}24 \\
21 \\
5\end{array}$ & $\begin{array}{c}1.0 \\
3.7(1.8-7.6) \\
5.9(2-17.3)\end{array}$ & 0.0001 \\
\hline $\begin{array}{l}\text { Premalignant lesion } \\
\text { Mild }^{c} \\
\text { Moderate } \\
\text { Severe }\end{array}$ & $\begin{array}{r}8 \\
115 \\
41\end{array}$ & $\begin{array}{r}4 \\
15 \\
1\end{array}$ & $\begin{array}{c}1.0 \\
3.3(0.9-12.6) \\
18.3(1.6-211.1)\end{array}$ & 0.004 \\
\hline $\begin{array}{l}\text { Intestinal-type GC } \\
\text { Mild }^{c} \\
\text { Moderate } \\
\text { Severe }\end{array}$ & $\begin{array}{r}3 \\
29 \\
6\end{array}$ & $\begin{array}{l}2 \\
5 \\
3\end{array}$ & $\begin{array}{c}1.0 \\
3.3(0.4-26.3) \\
3(0.1-12.8)\end{array}$ & 0.915 \\
\hline \multicolumn{5}{|l|}{ PMN infiltration } \\
\hline $\begin{array}{l}\text { Nonatrophic gastritis } \\
\text { None }{ }^{c} \\
\text { Mild } \\
\text { Moderate/severe }\end{array}$ & $\begin{array}{r}15 \\
59 \\
101\end{array}$ & $\begin{array}{l}23 \\
12 \\
15\end{array}$ & $\begin{array}{c}1.0 \\
7.7(3-19.4) \\
11.5(4.7-27.9)\end{array}$ & 0.0000 \\
\hline $\begin{array}{l}\text { Premalignant lesion } \\
\text { Nonec } \\
\text { Mild } \\
\text { Moderate/severe }\end{array}$ & $\begin{array}{r}10 \\
46 \\
108\end{array}$ & $\begin{array}{l}8 \\
4 \\
8\end{array}$ & $\begin{array}{c}1.0 \\
8.9(2.2-35.8) \\
10.2(3.1-33.9)\end{array}$ & 0.0002 \\
\hline $\begin{array}{l}\text { Intestinal-type GC } \\
\text { None }{ }^{c} \\
\text { Mild } \\
\text { Moderate/severe }\end{array}$ & $\begin{array}{r}4 \\
15 \\
20\end{array}$ & $\begin{array}{l}3 \\
4 \\
3\end{array}$ & $\begin{array}{c}1.0 \\
1.6(0.2-13.6) \\
7.5(0.8-72.3)\end{array}$ & 0.172 \\
\hline
\end{tabular}

Abbreviations: $\mathrm{Cl}=$ confidence interval; $\mathrm{EBV}=$ Epstein-Barr virus; $\mathrm{GC}=$ gastric cancer; $H P=$ Helicobacter pylori; $\mathrm{MN}=$ mononuclear; $\mathrm{OR}=$ odds ratio; $\mathrm{PMN}=$ polymorphonuclear . Numbers in bold denote statistical significance $(P<0.05)$.

a The $\chi^{2}$ for trend of positives (\%) found from mild to moderate to severe (for $\mathrm{MN}$ ) or none to mild to moderate-severe (for PMN) infiltration.

${ }^{\mathbf{b}} \mathrm{OR}$ adjusted for age and sex.

' Used as comparison group.

suggested that it may be importantly driven by causes other than inflammation.

Increasing evidence supports a link between EBV and GC, with a recent meta-analysis concluding that $\sim 9 \%$ of all GCs are positive to EBV (Murphy et al, 2009). However, Murphy et al (2009) only considered reports supporting a direct transforming role, in which EBV is infecting most tumour cells (e.g., searched by in situ hybridisation of viral transcripts). We have also found evidence of tumour cell infection by EBV in a similar percent of GCs (Martinez-Lopez et al, 2014). Early reports found EBV specifically associated with lymphoepiteliomas, a rare type of GC histologically similar to NPC (Shibata et al, 1991). More recent meta-analyses have found the virus in both intestinal- and diffuse-type GCs (Lee et al, 2009; Murphy et al, 2009; Li et al, 2010b), or preferentially associated with the diffuse type of GC (Camargo et al, 2011).

The association of $H P$ with early inflammatory precancerous lesions is well documented. However, only a few studies have analysed the participation of EBV infection in these lesions. Some studies have found evidence that EBV infects epithelial cells of the atrophic gastric mucosa with a relatively low frequency $(\leq 3 \%$ positive samples) (Hungermann et al, 2001; Zur Hausen et al, 


\begin{tabular}{|c|c|c|c|c|c|c|c|c|c|}
\hline & \multicolumn{9}{|c|}{ Gastric lesion } \\
\hline & & & & \multicolumn{6}{|c|}{ Gastric cancer } \\
\hline & $\begin{array}{c}\text { Nonatrophic } \\
\text { gastritis }^{b}\end{array}$ & \multicolumn{2}{|c|}{ Premalignant lesion } & \multicolumn{2}{|c|}{ Intestinal } & \multicolumn{2}{|c|}{ Diffuse } & \multicolumn{2}{|c|}{ Total GC } \\
\hline EBV IgG titres ${ }^{a}$ & $N$ & $N$ & OR $(95 \% \mathrm{Cl})$ & $N$ & OR $(95 \% \mathrm{Cl})$ & $N$ & OR $(95 \% \mathrm{Cl})$ & $N$ & OR $(95 \% \mathrm{Cl})$ \\
\hline \multicolumn{10}{|l|}{ Total, $\mathbf{M}+\mathbf{P}$} \\
\hline $\begin{array}{l}3.5-52.62 \\
52.63-87.09 \\
87.10-181.1 \\
P \text { for trend }\end{array}$ & $\begin{array}{l}75 \\
75 \\
75\end{array}$ & $\begin{array}{l}48 \\
56 \\
82\end{array}$ & $\begin{array}{c}1.0 \\
1.2(0.7-1.9) \\
1.7(1.1-2.8) \\
0.023\end{array}$ & $\begin{array}{l}12 \\
13 \\
25\end{array}$ & $\begin{array}{ll} & 1.0 \\
1.1 & (0.5-2.5) \\
2.1 & (0.97-4.5) \\
& \mathbf{0 . 0 3 8}\end{array}$ & $\begin{array}{l}22 \\
19 \\
23\end{array}$ & $\begin{array}{c}1.0 \\
0.9(0.4-1.7) \\
1.04(0.5-2) \\
0.856\end{array}$ & $\begin{array}{l}34 \\
32 \\
48\end{array}$ & $\begin{array}{c}1.0 \\
0.9(0.5-1.7) \\
1.4(0.8-2.4) \\
0.172\end{array}$ \\
\hline \multicolumn{10}{|c|}{ 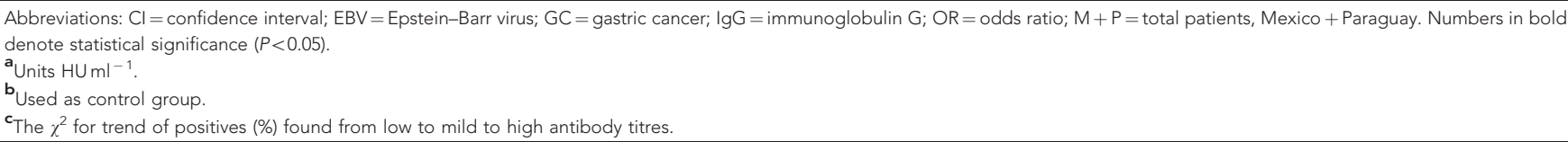 } \\
\hline
\end{tabular}

2004), whereas other studies favour frequencies of $\geq 50 \%$ (Ryan et al, 2012). Similarly, a few studies have addressed EBV serology in gastric disease with conflicting results (Levine et al, 1995; Shinkura et al, 2000; Koshiol et al, 2007; Schetter et al, 2008; Kim et al, 2009). Interestingly, we observed a positive association between EBV and severe infiltrate of MN and PMN cells in NAG (table 4), suggesting that the virus is inducing inflammation very early in the oncogenic pathway leading to intestinal type GC.

The EBV first and foremost documented mechanism for cell transformation is through direct infection and expression of viral oncogenes within the transforming cell. On the contrary, HP is considered the prototype cancer-inducing agent through chronic inflammation indirect mechanisms. However, a direct-transforming bacterial oncogene, $\operatorname{cag} A$, has been recently documented (Ohnishi et al, 2008; Miura et al, 2009), and an HP association with diffuse type of GC has been extensively documented (Huang et al, 1998). Because in our study we measured antibodies against an EBV reactivation antigen, our data suggest a positive association between EBV reactivation and severe inflammation in the gastric mucosa. We have recently made the same observation in pediatric patients, in which HP sole infection was not associated with severe inflammation, and the presence of EBV appeared necessary for that effect (Cardenas-Mondragon et al, 2013). It has been suggested that EBV reactivation from infected $B$ cells facilitates infection of epithelial cells (Sixbey and Yao, 1992; Imai et al, 1998; Faulkner et al, 1999; Shannon-Lowe and Rowe, 2011), and the titre of antiEBV reactivation antibodies has been shown to correlate with an increased risk of progression to NPC (Fachiroh et al, 2006; Ji et al, 2007; Li et al, 2010a).

How EBV and HP interact at the tissue or cellular level is not understood. Two possible mechanisms are envisioned: one is simply through additive inflammatory responses causing increased damage to the tissue. In that scenario, interleukin-1 $\beta$ (IL-1 $\beta$ ), tumour necrosis factor- $\alpha(\mathrm{TNF} \alpha)$ and interleukin- 8 (IL-8) are significantly elevated and associated to increased infiltration of immune cells in GC (Noach et al, 1994; Yamaoka et al, 1996; ElOmar et al, 2003) and in NPC (Huang et al, 1999; Chang et al, 2011; Li et al, 2012). A second mechanism is through more intimate interactions between EBV and HP genes. For instance, viral reactivation from infected $\mathrm{B}$ cells in vitro is induced by activation of the PLC $\gamma$ signalling pathway and CagA is a strong activator of PLC $\gamma$ (Churin et al, 2003).

Taken together, all these data suggest that EBV may contribute to GC carcinogenesis by both direct and indirect mechanisms: direct in $\sim 10 \%$ of cases in which the virus transforms the epithelial cells through expression of viral/cellular oncogenes; and indirect in perhaps a larger percent of GCs, in which viral reactivation favours severe chronic inflammatory responses, leading to increased tissue damage. In the latter scenario, there would not be clonal expansions of EBV-infected cells as the virus may reside in a cell different than the tumour cell. Considering that $H P$ also encodes the CagA oncoprotein, EBV and HP may transform the gastric epithelium through a combination of direct and indirect mechanisms, similar to hepatitis $\mathrm{B}$ and $\mathrm{C}$ virus (HBV and HCV)-induced hepatocellular carcinoma (Nikolaou et al, 2013). The importance of this observation is that individuals with a high risk of progression to GC, because of augmented viral reactivation and advanced gastric lesions, may benefit from pharmacological treatment targeting EBV lytic-cycle proteins.

Study limitations. This is a case-control study of patients with gastric disease in which premalignant and malignant lesions were compared with NAG, the earliest inflammatory lesion in the progression to intestinal and diffuse GCs. Molecular studies addressing how EBV and HP cooperate to increase inflammatory responses together with longitudinal studies in a cohort of patients addressing GC progression are necessary to obtain more conclusive evidence supporting a causative indirect transforming role for EBV in gastric carcinogenesis. In addition, we initially anticipated using $H P$ and EBV double-negative patients as the control group, but the low number of these patients $(n=3)$ precluded its use; hence, the $H P+/ E B V+$ group was compared with patients with single $H P$ or EBV infection. However, this may be a more rigorous comparison to address the joint role of both pathogens in gastric disease. In our stratified statistical analysis we often ended with cells with low numbers $(n \leq 10)$, including no EBV-negative patients with intestinal-type GC. Still, our data show significant associations of $\mathrm{EBV}+/ \mathrm{HP}+$ with intestinal GC and its inflammatory precursor lesions, and no associations with diffuse GC, in spite that some of these patients show severe inflammation. Finally, in this study statistical data were adjusted only for age and sex confounders, and other documented confounders, such as smoking, salt ingestion and so on, should be addressed in future studies.

\section{ACKNOWLEDGEMENTS}

This study was supported by Grant FIS/IMSS/PROT/G2011/941 (to MG Cárdenas-Mondragón), Grants 178199 (to MG CárdenasMondragón), 176880 (to EM Fuentes-Pananá) and 69450 (to J Torres) from CONACYT and Grant HIM-2013-051 (to EM Fuentes Pananá) from Fondo de Apoyo a la Investigación, Hospital Infantil de México Federico Gómez. 


\section{AUTHOR CONTRIBUTIONS}

MGC-M and RC-T performed the experiments, JT and EMF-P designed the study, JT, MC-P and EK recruited all patients included in the study, LF-L, MGC-M and AG-D performed the statistical analysis, MGC-M, JT, LF-L and EMF-P wrote the manuscript.

\section{REFERENCES}

Camargo MC, Murphy G, Koriyama C, Pfeiffer RM, Kim WH, Herrera-Goepfert R, Corvalan AH, Carrascal E, Abdirad A, Anwar M, Hao Z, Kattoor J, Yoshiwara-Wakabayashi E, Eizuru Y, Rabkin CS, Akiba S (2011) Determinants of Epstein-Barr virus-positive gastric cancer: an international pooled analysis. Br J Cancer 105: 38-43.

Camorlinga-Ponce M, Flores-Luna L, Lazcano-Ponce E, Herrero R, Bernal-Sahagun F, Abdo-Francis JM, Aguirre-Garcia J, Munoz N, Torres J (2008) Age and severity of mucosal lesions influence the performance of serologic markers in Helicobacter pylori-associated gastroduodenal pathologies. Cancer Epidemiol Biomarkers Prev 17: 2498-2504.

Camorlinga-Ponce $\mathrm{M}$, Torres J, Perez-Perez G, Leal-Herrera Y, Gonzalez-Ortiz B, Madrazo de la Garza A, Gomez A, Munoz O (1998) Validation of a serologic test for the diagnosis of Helicobacter pylori infection and the immune response to urease and CagA in children. Am J Gastroenterol 93: 1264-1270.

Cardenas-Mondragon MG, Carreon-Talavera R, Camorlinga-Ponce M, Gomez-Delgado A, Torres J, Fuentes-Panana EM (2013) Epstein Barr virus and Helicobacter pylori co-infection are positively associated with severe gastritis in pediatric patients. PLoS One 8: e62850.

Correa P, Haenszel W, Cuello C, Tannenbaum S, Archer M (1975) A model for gastric cancer epidemiology. Lancet 2: 58-60.

Chang KP, Chang YT, Wu CC, Liu YL, Chen MC, Tsang NM, Hsu CL, Chang YS, Yu JS (2011) Multiplexed immunobead-based profiling of cytokine markers for detection of nasopharyngeal carcinoma and prognosis of patient survival. Head Neck 33: 886-897.

Churin Y, Al-Ghoul L, Kepp O, Meyer TF, Birchmeier W, Naumann M (2003) Helicobacter pylori CagA protein targets the c-Met receptor and enhances the motogenic response. J Cell Biol 161: 249-255.

Dixon MF, Genta RM, Yardley JH, Correa P (1996) Classification and grading of gastritis. The updated Sydney System. International Workshop on the Histopathology of Gastritis, Houston 1994. Am J Surg Pathol 20: 1161-1181.

El-Omar EM, Rabkin CS, Gammon MD, Vaughan TL, Risch HA, Schoenberg JB, Stanford JL, Mayne ST, Goedert J, Blot WJ, Fraumeni Jr. JF Chow WH (2003) Increased risk of noncardia gastric cancer associated with proinflammatory cytokine gene polymorphisms. Gastroenterology 124: 1193-1201.

Fachiroh J, Paramita DK, Hariwiyanto B, Harijadi A, Dahlia HL, Indrasari SR, Kusumo H, Zeng YS, Schouten T, Mubarika S, Middeldorp JM (2006) Single-assay combination of Epstein-Barr virus (EBV) EBNA1- and viral capsid antigen-p18-derived synthetic peptides for measuring anti-EBV immunoglobulin $\mathrm{G}(\mathrm{IgG})$ and IgA antibody levels in sera from nasopharyngeal carcinoma patients: options for field screening. J Clin Microbiol 44: 1459-1467.

Faulkner GC, Burrows SR, Khanna R, Moss DJ, Bird AG, Crawford DH (1999) X-linked agammaglobulinemia patients are not infected with Epstein-Barr virus: implications for the biology of the virus. J Virol 73: $1555-1564$.

Ferlay J, Soerjomataram I, Ervik M, Dikshit R, Eser S, Mathers C, Rebelo M, Parkin DM, Formann D, Bray F (2013) GLOBOCAN 2012 v1.0. Cancer Incidence and Mortality Wordwide: IARC CancerBase No.11 [Internet] Vol. 2013. International Agency for Research on Cancer: Lyon, France.

Flores-Luna L, Camorlinga-Ponce M, Hernandez-Suarez G, Kasamatsu E, Martinez ME, Murillo R, Lazcano E, Torres J (2012) The utility of serologic tests as biomarkers for Helicobacter pylori-associated precancerous lesions and gastric cancer varies between Latin American countries. Cancer Causes Control 24: 241-248.

Frappier L (2012) Contributions of Epstein-Barr nuclear antigen 1 (EBNA1) to cell immortalization and survival. Viruses 4: 1537-1547.

Fuccio L, Eusebi LH, Bazzoli F (2010) Gastric cancer, Helicobacter pylori infection and other risk factors. World J Gastrointest Oncol 2: 342-347.
Guilford P, Hopkins J, Harraway J, McLeod M, McLeod N, Harawira P, Taite H, Scoular R, Miller A, Reeve AE (1998) E-cadherin germline mutations in familial gastric cancer. Nature 392: 402-405.

Huang JQ, Sridhar S, Chen Y, Hunt RH (1998) Meta-analysis of the relationship between Helicobacter pylori seropositivity and gastric cancer. Gastroenterology 114: 1169-1179.

Huang YT, Sheen TS, Chen CL, Lu J, Chang Y, Chen JY, Tsai CH (1999) Profile of cytokine expression in nasopharyngeal carcinomas: a distinct expression of interleukin 1 in tumor and CD4 $+\mathrm{T}$ cells. Cancer Res 59: 1599-1605.

Hungermann D, Muller S, Spieker T, Lisner R, Niedobitek G, Herbst H (2001) Low prevalence of latently Epstein-Barr virus-infected cells in chronic gastritis. Microsc Res Tech 53: 409-413.

Imai S, Nishikawa J, Takada K (1998) Cell-to-cell contact as an efficient mode of Epstein-Barr virus infection of diverse human epithelial cells. J Virol 72: 4371-4378.

Ji MF, Wang DK, Yu YL, Guo YQ, Liang JS, Cheng WM, Zong YS, Chan KH, Ng SP, Wei WI, Chua DT, Sham JS, Ng MH (2007) Sustained elevation of Epstein-Barr virus antibody levels preceding clinical onset of nasopharyngeal carcinoma. Br J Cancer 96: 623-630.

Kasamatsu E, Bravo LE, Bravo JC, Aguirre-Garcia J, Flores-Luna L, NunesVelloso Mdel C, Hernandez-Suarez G (2010) Reproducibility of histopathologic diagnosis of precursor lesions of gastric carcinoma in three Latin American countries. Salud Publica Mex 52: 386-390.

Kim Y, Shin A, Gwack J, Ko KP, Kim CS, Park SK, Hong YC, Kang D, Yoo KY (2009) Epstein-Barr virus antibody level and gastric cancer risk in Korea: a nested case-control study. Br J Cancer 101: 526-529.

Kokkola A, Kosunen TU, Puolakkainen P, Sipponen P, Harkonen M, Laxen F, Virtamo J, Haapiainen R, Rautelin H (2003) Spontaneous disappearance of Helicobacter pylori antibodies in patients with advanced atrophic corpus gastritis. APMIS 111: 619-624.

Koshiol J, Qiao YL, Mark SD, Dawsey SM, Abnet CC, Kamangar F, Lennette ET, Dong ZW, Taylor PR (2007) Epstein-Barr virus serology and gastric cancer incidence and survival. Br J Cancer 97: 1567-1569.

Lee JH, Kim SH, Han SH, An JS, Lee ES, Kim YS (2009) Clinicopathological and molecular characteristics of Epstein-Barr virus-associated gastric carcinoma: a meta-analysis. J Gastroenterol Hepatol 24: 354-365.

Levine PH, Stemmermann G, Lennette ET, Hildesheim A, Shibata D, Nomura A (1995) Elevated antibody titers to Epstein-Barr virus prior to the diagnosis of Epstein-Barr-virus-associated gastric adenocarcinoma. Int J Cancer 60: 642-644.

Li S, Deng Y, Li X, Chen QP, Liao XC, Qin X (2010a) Diagnostic value of Epstein-Barr virus capsid antigen-IgA in nasopharyngeal carcinoma: a meta-analysis. Chin Med J (Engl) 123: 1201-1205.

Li S, Du H, Wang Z, Zhou L, Zhao X, Zeng Y (2010b) Meta-analysis of the relationship between Epstein-Barr virus infection and clinicopathological features of patients with gastric carcinoma. Sci China Life Sci 53: 524-530.

Li XJ, Peng LX, Shao JY, Lu WH, Zhang JX, Chen S, Chen ZY, Xiang YQ, Bao YN, Zheng FJ, Zeng MS, Kang TB, Zeng YX, Teh BT, Qian CN (2012) As an independent unfavorable prognostic factor, IL-8 promotes metastasis of nasopharyngeal carcinoma through induction of epithelial-mesenchymal transition and activation of AKT signaling. Carcinogenesis 33: 1302-1309.

Martinez-Lopez JL, Torres J, Camorlinga-Ponce M, Mantilla A, Leal YA, Fuentes-Panana EM (2014) Evidence of Epstein-Barr virus association with gastric cancer and non-atrophic gastritis. Viruses 6: 301-318.

Miura M, Ohnishi N, Tanaka S, Yanagiya K, Hatakeyama M (2009) Differential oncogenic potential of geographically distinct Helicobacter pylori CagA isoforms in mice. Int J Cancer 125: 2497-2504.

Morales-Sanchez A, Fuentes-Panana EM (2014) Human viruses and cancer. Viruses 6: 4047-4079.

Murphy G, Pfeiffer R, Camargo MC, Rabkin CS (2009) Meta-analysis shows that prevalence of Epstein-Barr virus-positive gastric cancer differs based on sex and anatomic location. Gastroenterology 137: 824-833.

Nikolaou K, Sarris M, Talianidis I (2013) Molecular pathways: the complex roles of inflammation pathways in the development and treatment of liver cancer. Clin Cancer Res 19: 2810-2816.

Noach LA, Bosma NB, Jansen J, Hoek FJ, van Deventer SJ, Tytgat GN (1994) Mucosal tumor necrosis factor-alpha, interleukin-1 beta, and interleukin-8 production in patients with Helicobacter pylori infection. Scand $J$ Gastroenterol 29: 425-429.

Ohnishi N, Yuasa H, Tanaka S, Sawa H, Miura M, Matsui A, Higashi H, Musashi M, Iwabuchi K, Suzuki M, Yamada G, Azuma T, Hatakeyama M (2008) Transgenic expression of Helicobacter pylori CagA induces 
gastrointestinal and hematopoietic neoplasms in mouse. Proc Natl Acad Sci USA 105: 1003-1008.

Ryan JL, Shen YJ, Morgan DR, Thorne LB, Kenney SC, Dominguez RL, Gulley ML (2012) Epstein-Barr virus infection is common in inflamed gastrointestinal mucosa. Dig Dis Sci 57: 1887-1898.

Saha A, Robertson ES (2013) Impact of EBV essential nuclear protein EBNA-3C on B-cell proliferation and apoptosis. Future Microbiol 8: 323-352.

Schetter AJ, You WC, Lennette ET, Gail MT, Rabkin CS (2008) Association of Epstein-Barr virus antibody levels with precancerous gastric lesions in a high-risk cohort. Cancer Sci 99: 350-354.

Shair KH, Bendt KM, Edwards RH, Nielsen JN, Moore DT, Raab-Traub N (2012) Epstein-Barr virus-encoded latent membrane protein 1 (LMP1) and LMP2A function cooperatively to promote carcinoma development in a mouse carcinogenesis model. J Virol 86: 5352-5365.

Shannon-Lowe C, Rowe M (2011) Epstein-Barr virus infection of polarized epithelial cells via the basolateral surface by memory B cell-mediated transfer infection. PLoS Pathog 7: e1001338.

Shibata D, Tokunaga M, Uemura Y, Sato E, Tanaka S, Weiss LM (1991) Association of Epstein-Barr virus with undifferentiated gastric carcinomas with intense lymphoid infiltration. Lymphoepithelioma-like carcinoma. Am J Pathol 139: 469-474.

Shinkura R, Yamamoto N, Koriyama C, Shinmura Y, Eizuru Y, Tokunaga M (2000) Epstein-Barr virus-specific antibodies in Epstein-Barr virus-positive and -negative gastric carcinoma cases in Japan. J Med Virol 60: $411-416$.

Sixbey JW, Yao QY (1992) Immunoglobulin A-induced shift of Epstein-Barr virus tissue tropism. Science 255: 1578-1580.

Thorley-Lawson DA, Gross A (2004) Persistence of the Epstein-Barr virus and the origins of associated lymphomas. N Engl J Med 350: 1328-1337.

Thornburg NJ, Kulwichit W, Edwards RH, Shair KH, Bendt KM, Raab-Traub N (2006) LMP1 signaling and activation of NF-kappaB in LMP1 transgenic mice. Oncogene 25: 288-297.

Yamaoka Y, Kita M, Kodama T, Sawai N, Imanishi J (1996) Helicobacter pylori cagA gene and expression of cytokine messenger RNA in gastric mucosa. Gastroenterology 110: 1744-1752.

Zur Hausen A, van Rees BP, van Beek J, Craanen ME, Bloemena E, Offerhaus GJ, Meijer CJ, van den Brule AJ (2004) Epstein-Barr virus in gastric carcinomas and gastric stump carcinomas: a late event in gastric carcinogenesis. J Clin Pathol 57: 487-491.

This work is published under the standard license to publish agreement. After 12 months the work will become freely available and the license terms will switch to a Creative Commons AttributionNonCommercial-Share Alike 4.0 Unported License.

Supplementary Information accompanies this paper on British Journal of Cancer website (http://www.nature.com/bjc) 